\title{
KARAKTERISTIK FISIKOKIMIA DAN ORGANOLEPTIK FRUIT LEATHER KENITU (Chrysophyllum cainito L.) DENGAN PENAMBAHAN CMC DAN KARAGENAN
}

Physicochemical and Organoleptic Characteristics of Fruit Leather from Star Apple (Chrysophyllum cainito L.) Added with CMC and Carrageenan

\author{
Herlina Herlina $^{1) *}$, Maria Belgis ${ }^{1}$, Lufi Wirantika ${ }^{1)}$ \\ 1)Jurusan Teknologi Hasil Pertanian, Fakultas Teknologi Pertanian, Universitas Jember \\ Jalan Kalimantan No. 37 Kampus Tegal Boto Jember \\ *Korespondensi Penulis: lina.ftp@ unej.ac.id
}

\begin{abstract}
Star apple is a seasonal local fruit that is commonly found in East Java, Indonesia. This fruit contains high fiber and antioxidants, however the utilization was not optimal specially at the harvest season, so it requires for further processing. Star fruit apple processing into fruit leather would expected to resolve this problem. Plasticity is an important parameter in fruit leather quality which can be influenced by binding agent, sugar, and acid composition. Therefore, the aim of this study was to determine the best concentration of binding agent that can produce star apple fruit leathers with good characteristics and preferred by consumers. The concentration of CMC and carrageenan used in this study were $0.1 \%$; 0.3\%; 0.5\%. Physicochemical data were analyzed by ANOVA $(\alpha=5 \%)$ and DMRT, while preference were analyzed using Chi-square test $(\alpha=5 \%)$. The best treatment determination was using scoring analysis. The result showed that $0.3 \%$ carrageenan was the best treatment to produce star apple fruit leather with 54.48 lightness, $348 \mathrm{~g} / 2 \mathrm{~mm}$ texture, $17.99 \mathrm{KPa}$ tensile strength, $9.03 \%$ elongation, $2.68 \%$ syneresis, $22.49 \%$ water content, and $6.11 \%$ crude fiber content. While the color, aroma, texture, taste, and overall preference were as follows $73.33 \%$, $63.33 \%, 73.33 \%, 60 \%$, and $66.67 \%$ respectively.
\end{abstract}

Keywords: CMC, carrageenan, fruit leather, star apple

\section{PENDAHULUAN}

Kenitu (Chrysophyllum cainito L.) merupakan salah satu buah lokal musiman yang banyak dijumpai di Jawa Timur khususnya di Kabupaten Banyuwangi, Jember, Bondowoso, Situbondo, Lumajang, dan Probolinggo (Taruna \& Sutarsih, 2011). Kenitu merupakan buah non-klimaterik yang mengandung nutrisi dan antioksidan tinggi sehingga dapat memberikan efek sehat bagi tubuh (Yahia \& Orozco, 2011). Selain itu, kenitu juga mengandung fosfor dan kalsium yang berfungsi untuk mencegah hipertensi, kanker usus besar, batu ginjal, serta menjaga kesehatan tulang dan gigi (Taruna \& Sutarsih, 2011). Kenitu juga mengandung senyawa polifenol antioksidan seperti catechin, epicatechin, gallocatechin, epigallocatechin, quercetin, quercitrin, isoquercitrin, myricitrin, dan gallic acid (Luo et al., 2002).

Saat memasuki musim panen, produksi kenitu sangat melimpah, dan umur simpannya yang relatif singkat membuat harga jualnya menjadi rendah. Selain itu, produk olahan kenitu juga masih sangat terbatas di pasaran. Kenitu dengan kandungan senyawa polifenol dan serat yang cukup tinggi berpotensi untuk diolah menjadi produk pangan olahan sehingga dapat meningkatkan nilai jualnya (Taruna \& Sutarsih, 2011).

Fruit leather merupakan salah satu produk pangan sejenis manisan kering berbentuk lembaran tipis, cita rasa khas sesuai dengan buah yang digunakan, dan memiliki nilai ekonomis di pasar 
internasional (Raab \& Oehler, 2000). Fruit leather memiliki kelebihan, antara lain lebih praktis, memiliki umur simpan yang lebih panjang dibandingkan dengan buah segar, serta nutrisinya tidak banyak berubah (Kwartiningsih \& Mulyati, 2005). Karakteristik yang diharapkan dari fruit leather adalah memiliki warna yang menarik, tekstur yang sedikit liat dan kompak, serta memiliki plastisitas yang baik sehingga dapat digulung (tidak mudah patah atau sobek) (Rosida et al., 2016).

Bahan baku yang digunakan dalam pembuatan fruit leather dapat berasal dari berbagai macam jenis buah-buahan tropis maupun subtropis (Nuh, 2018). Pada penelitian Rahman et al. (2016), penggunaan bahan yang kurang atau mengandung sedikit serat menghasilkan fruit leather yang lunak dan tidak kompak, karena serat mampu mengikat air dan mempertahankan tekstur. Kenitu berpotensi untuk diolah menjadi fruit leather karena mengandung serat yang cukup tinggi yaitu sebesar 0,55-3,30 g/ 100 $\mathrm{g}$ bagian yang dapat dimakan (Ruiz \& Pavon, 1999).

Masalah yang sering timbul pada fruit leather yaitu mengenai plastisitasnya. Salah satu faktor yang mempengaruhi plastisitas fruit leather adalah penggunaan bahan pengikat. Beberapa bahan pengikat yang sering digunakan adalah karagenan dan CMC (Kusbiantoro et al., 2005). Sidi et al. (2014) menyebutkan bahwa karagenan dapat digunakan untuk memperbaiki tekstur dari fruit leather. CMC dan karagenan merupakan hidrokoloid yang mudah larut dalam air, membentuk tekstur yang kompak, mencegah sineresis, mudah didapat, dan harganya murah. Namun, jenis dan konsentrasi bahan pengikat yang terbaik (CMC atau karagenan) yang tepat untuk menghasilkan fruit leather kenitu dengan karakteristik terbaik dan disukai konsumen belum diketahui sebelumnya. Oleh karena itu, penelitian ini dilakukan untuk mengetahui jenis dan konsentrasi bahan pengikat yang tepat dalam pembuatan fruit leather kenitu.

\section{METODE PENELITIAN}

\section{Alat dan Bahan}

Peralatan yang digunakan antara lain color reader (Konica Minolta CR-10), rheotex (Tipe SD-700), universal testing machine (Shimadzu EZ Test), thickness gage (Mitutoyo Dial Tipe 7301), pendingin balik, oven $105^{\circ} \mathrm{C}$ (Memmert), cabinet dryer $60^{\circ} \mathrm{C}$, neraca analitik (Ohaus Pioneer), kompor gas (Gorenje), blender (Miyako BL-152 PF-AP), wajan teflon (Maxim Valentino), botol timbang, dan peralatan gelas lainnya.

Bahan baku yang digunakan yaitu kenitu hijau yang matang secara fisiologis (tekstur lunak dan beraroma manis) yang diperoleh dari pemasok kenitu di Kabupaten Bondowoso. Bahan lainnya meliputi air, gula kristal putih (Gulaku), asam sitrat, $\mathrm{CMC}$, dan $\kappa$-karagenan. Bahan kimia yang digunakan untuk analisis meliputi $\mathrm{K}_{2} \mathrm{SO}_{4}$ (Merck), $\mathrm{H}_{2} \mathrm{SO}_{4}$ (Merck), $\mathrm{NaOH}$ (Merck), dan alkohol (teknis).

\section{Tahapan Penelitian}

\section{Pembuatan Puree Kenitu}

Kenitu dicuci dan daging buahnya dipisahkan dari kulit dan bijinya. Selanjutnya dihancurkan dengan blender selama 3 menit dengan penambahan air 1:1 (b/b).

\section{Pembuatan Fruit Leather Kenitu}

Proses pembuatan fruit leather mengacu pada Marzelly et al. (2017) yang sudah dimodifikasi. Puree kenitu yang telah ditimbang dicampurkan dengan gula kristal putih, asam sitrat, CMC, dan karagenan sesuai perlakuan (Tabel 1). Adonan selanjutnya dicampur dengan blender selama 2 menit dan dipanaskan pada suhu $100^{\circ} \mathrm{C}$ selama 4 menit dalam teflon, dituang ke dalam loyang yang dilapisi kain silpat agar tidak lengket, dan 
dikeringkan menggunakan cabinet dryer dengan suhu $60^{\circ} \mathrm{C}$ selama 25 jam.

\section{Rancangan Percobaan}

Penelitian ini menggunakan rancangan acak lengkap (RAL) dengan dua faktor yaitu jenis dan konsentrasi bahan pengikat. Jenis bahan pengikat terdiri dari CMC dan karagenan, sedangkan konsentrasi bahan pengikat terdiri dari tiga (3) taraf yaitu $0,1 \% \mathrm{~b} / \mathrm{b} ; 0,3 \% \mathrm{~b} / \mathrm{b} ; 0,5 \%$ $\mathrm{b} / \mathrm{b}$ terhadap $500 \mathrm{~g}$ total bahan dengan tiga (3) kali ulangan pada masing-masing perlakuan. Kombinasi dua faktor dan formulasi fruit leather kenitu dapat dilihat pada Tabel 1. Data hasil pengamatan sifat fisik dan kimia diolah menggunakan ANOVA $(\alpha=5 \%)$ dan diuji lanjut menggunakan DMRT sedangkan data organoleptik diolah menggunakan Chisquare $(\alpha=5 \%)$. Perlakuan terbaik ditentukan secara deskriptif kualitatif dengan pembobotan nilai yang mengacu pada Sugiyono (2016) yang dimodifikasi.

Tabel 1. Kombinasi dua faktor dan formulasi fruit leather kenitu

\begin{tabular}{|c|c|c|c|c|c|c|}
\hline \multirow[b]{2}{*}{ 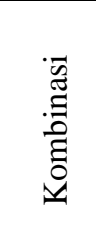 } & \multicolumn{5}{|c|}{ Bahan (g) } & \multirow[b]{2}{*}{$\stackrel{\frac{\pi}{0}}{0}$} \\
\hline & $\frac{v}{0}$ & 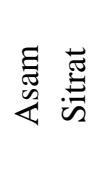 & 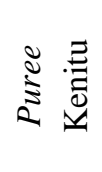 & $\sum_{U}^{U}$ & 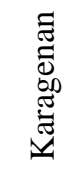 & \\
\hline A1B 1 & 50 & 0,5 & 449 & 0,5 & 0 & 500 \\
\hline AIB2 & 50 & 0,5 & 448 & 1,5 & 0 & 500 \\
\hline AIB3 & 50 & 0,5 & 447 & 2,5 & 0 & 500 \\
\hline $\mathrm{A} 2 \mathrm{~B} 1$ & 50 & 0,5 & 449 & 0 & 0,5 & 500 \\
\hline $\mathrm{A} 2 \mathrm{~B} 2$ & 50 & 0,5 & 448 & 0 & 1,5 & 500 \\
\hline A2B3 & 50 & 0,5 & 447 & 0 & 2,5 & 500 \\
\hline
\end{tabular}

Keterangan: A1 (CMC), A2 (karagenan), B1 $(0,1 \%)$, B2 $(0,3 \%)$, dan B3 $(0,5 \%)$

\section{Metode Analisis}

Fruit leather kenitu diuji secara fisik, kimia, dan organoleptik. Uji fisik meliputi kecerahan warna (lightness) (Pomeranz \& Meloans, 1994), tekstur dilakukan dengan rheotex (Marzelly et al., 2017), kuat tarik (ASTM, 1995), elongasi (ASTM, 1995), dan sineresis (Herbstreith \& Fox, 2009). Uji kimia meliputi kadar air metode termogravimetri (AOAC, 2005) dan kadar serat kasar (Sudarmadji et al., 1997).

Pengujian organoleptik dilakukan secara hedonik (kesukaan) meliputi warna, aroma, tekstur, rasa, dan keseluruhan menggunakan 30 orang panelis tidak terlatih berusia 18-22 tahun (9 laki-laki dan 21 perempuan). Panelis diminta memberikan skor 1-7 dengan rincian:

1 = sangat tidak suka;

2 = tidak suka;

3 = agak tidak suka;

$4=$ netral $/$ biasa;

5 = agak suka;

$6=$ suka; dan

7 = sangat suka

Penentuan perlakuan terbaik mengacu pada Sugiyono (2016) yang sudah dimodifikasi. Penentuan ini dilakukan secara deskriptif kualitatif yaitu memberikan tanda centang pada setiap sampel sesuai dengan yang dikehendaki kemudian dilanjutkan dengan pembobotan nilai. Nilai yang semakin tinggi menunjukkan bahwa sampel tersebut semakin mendekati parameter yang dikehendaki. Rincian nilai yang digunakan yaitu 4 untuk parameter yang sesuai dengan SNI01-1718-1996, sedangkan yang tidak sesuai diberi nilai terendah (0).

\section{HASIL DAN PEMBAHASAN}

\section{Karakteristik Fisik Fruit Leather Kenitu}

\section{Kecerahan Warna (Lightness) Fruit Leather Kenitu}

Warna merupakan faktor mutu yang paling menarik perhatian konsumen dan paling cepat mempengaruhi penerimaan (Winarno, 1992). Hasil sidik ragam $(\alpha=$ $5 \%$ menunjukkan variasi jenis dan konsentrasi bahan pengikat berpengaruh nyata terhadap nilai kecerahan warna fruit leather kenitu, sedangkan interaksi keduanya tidak berpengaruh nyata. Nilai 
kecerahan warna (lightness) fruit leather kenitu dengan variasi jenis dan konsentrasi bahan pengikat ditunjukkan pada Gambar 1.

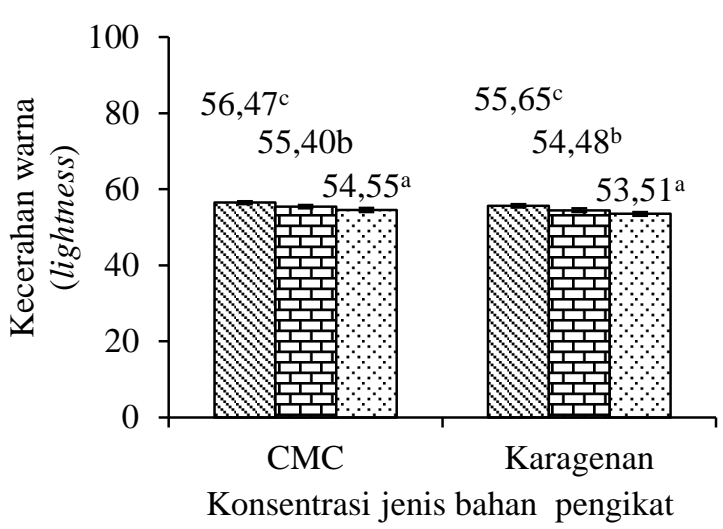

Gambar 1. Nilai kecerahan warna (lightness) fruit leather kenitu dengan variasi konsentrasi jenis bahan pengikat $0,1 \%$ (囚); 0,3\% (四); dan 0,5\% (

Fruit leather kenitu dengan penambahan CMC menghasilkan warna yang lebih cerah dibandingkan dengan penambahan karagenan karena kemampuan CMC dalam mengikat air lebih kecil dari karagenan. Menurut Tondang et al. (2018) semakin tinggi penggunaan karagenan, maka semakin tinggi pula kandungan serat pada fruit leather. Jumlah serat akan mempengaruhi jumlah air yang terikat. Kandungan serat yang tinggi meningkatkan kemampuan menyerap air karena di dalam serat terdapat cukup banyak gugus hidroksil bebas yang bersifat polar (Santoso, 2011).

Karagenan mengandung total serat pangan lebih tinggi dibandingkan dengan CMC, yakni sebesar 83,62 g/ $100 \mathrm{~g}$ (Santoso et al., 2004), sedangkan kandungan serat pada CMC sebesar $74 \mathrm{~g} /$ $100 \mathrm{~g}$ (Muzaifa, 2006). Oleh karena itu, kemampuan menyerap air yang semakin kuat akan membuat warna yang dihasilkan semakin pekat.

Fruit leather kenitu memiliki warna yang semakin gelap seiring dengan meningkatnya konsentrasi bahan pengikat.
Kecerahan warna pada fruit leather kenitu dapat dipengaruhi oleh adanya reaksi pencoklatan enzimatis pada saat pemisahan daging kenitu dari kulit dan bijinya karena adanya pemotongan sehingga dapat merusak jaringan buah tersebut. Reaksi ini kemungkinan terus terjadi sebelum daging kenitu dihancurkan menggunakan blender dengan ditambahkan air. Pencoklatan tersebut dapat membuat warna daging kenitu yang awalnya putih susu berubah menjadi putih kekuningan (putih tulang). Selain itu, proses pengolahan juga dapat mempengaruhi kecerahan warna fruit leather kenitu yang dihasilkan. Pada saat pemanasan dan pengovenan terjadi reaksi maillard (reaksi pencoklatan non-enzimatis yakni reaksi antara gugus karbonil dengan gugus amino dalam bahan). Reaksi ini melibatkan beberapa reaksi kompleks hingga dihasilkan senyawa melanoidin berwana coklat (Sugiyono, 2004). Karamelisasi mungkin saja juga mempengaruhi kecerahan warna fruit leather kenitu karena adanya proses pengeringan menggunakan cabinet dryer (suhu $60^{\circ} \mathrm{C}, 25 \mathrm{jam}$ ) dan pemanasan (suhu $100^{\circ} \mathrm{C}, 4$ menit).

\section{Tekstur (Kekerasan) Fruit Leather Kenitu}

Hasil sidik ragam $(\alpha=5 \%)$ menunjukkan variasi jenis dan konsentrasi bahan pengikat berpengaruh nyata terhadap tekstur fruit leather kenitu, sedangkan interaksi keduanya tidak berpengaruh nyata. Nilai tekstur fruit leather kenitu dengan variasi jenis dan konsentrasi bahan pengikat ditunjukkan pada Gambar 2.

Fruit leather kenitu dengan penambahan karagenan menghasilkan tekstur yang lebih lunak daripada fruit leather kenitu dengan penambahan CMC karena adanya perbedaan kandungan serat pada kedua bahan pengikat tersebut. Karagenan mengandung total serat pangan lebih tinggi, yakni sebesar 83,62 g/ $100 \mathrm{~g}$ (Santoso et al., 2004), sedangkan kandungan serat pada CMC sebesar $74 \mathrm{~g} /$ 100 g (Muzaifa, 2006). Jenis karagenan 
yang digunakan dalam penelitian ini yaitu kappa karagenan, penggunaan karagenan dapat mempengaruhi tekstur fruit leather menjadi kenyal atau lunak (Tondang et al., 2018). Kandungan serat yang tinggi meningkatkan kemampuan menyerap air karena di dalam serat terdapat cukup banyak gugus hidroksil bebas yang bersifat polar (Santoso, 2011).

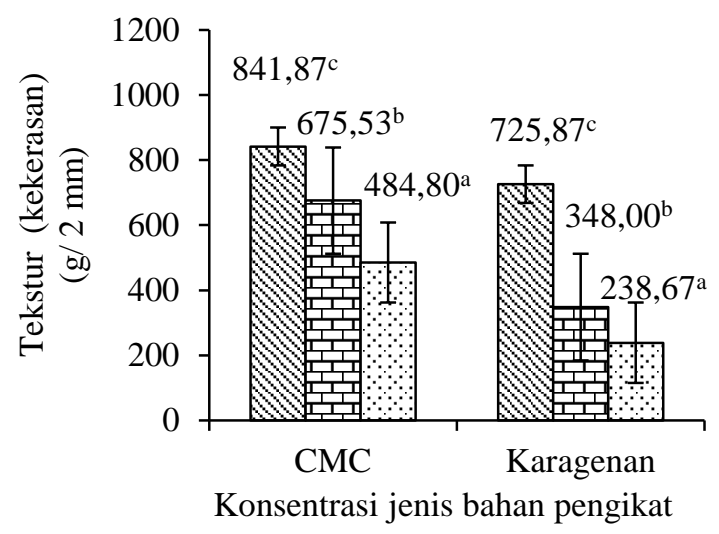

Gambar 2. Tekstur fruit leather kenitu dengan variasi konsentrasi jenis bahan pengikat $0,1 \%$ (\$) $) ; 0,3 \%$ (臣); dan $0,5 \%(\because \because)$

Fruit leather kenitu memiliki tekstur yang semakin lunak dengan semakin tingginya konsentrasi bahan pengikat yang ditambahkan. Hal tersebut terjadi karena air yang terikat dalam jaringan hidrokoloid (bahan pengikat) semakin banyak. Menurut Pietrasik \& Jarmolouk (2003), semakin tinggi hidrokoloid yang ditambahkan maka akan meningkatkan kekompakan matriks gel sehingga dapat mengurangi struktur berongga yang dapat menurunkan kekenyalan dan meningkatkan kekerasan. Morris (1998) menyatakan bahwa struktur gel yang semakin kokoh menunjukkan bahwa air yang terperangkap semakin banyak karena air yang menguap selama proses pengeringan semakin sedikit sehingga terjadi peningkatan kadar air dan bertekstur lunak.

\section{Kuat Tarik Fruit Leather Kenitu \\ Fruit leather kenitu yang memiliki nilai kekuatan tarik tertinggi berarti}

memiliki ketahanan terhadap gaya tarik yang lebih baik sehingga tidak mudah putus dan sobek. Hasil sidik ragam $(\alpha=$ 5\%) menunjukkan bahwa variasi jenis dan konsentrasi bahan pengikat berpengaruh nyata terhadap nilai kuat tarik fruit leather kenitu, sedangkan interaksi keduanya berpengaruh tidak nyata. Nilai kuat tarik fruit leather kenitu dengan variasi jenis dan konsentrasi bahan pengikat dapat dilihat pada Gambar 3.

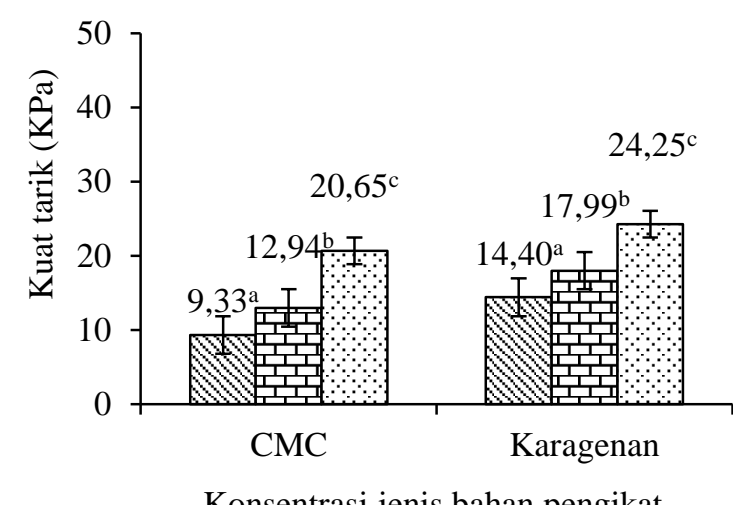

Gambar 3. Nilai kuat tarik fruit leather kenitu dengan variasi konsentrasi jenis bahan pengikat $0,1 \%(\mathbb{N}) ; 0,3 \%$ (臣); dan $0,5 \%$ (두)

Fruit leather kenitu dengan penambahan karagenan menghasilkan kuat tarik lebih tinggi daripada penambahan CMC. Nilai kuat tarik berbanding terbalik dengan nilai tekstur. Semakin kecil nilai tekstur maka nilai kuat tarik semakin besar. Fruit leather kenitu dengan jaringan yang kompak cenderung memiliki tekstur lebih liat dan lebih susah putus karena adanya penambahan hidrokoloid yang dapat mengikat air dalam bahan (Pietrasik \& Jarmolouk, 2003). Air yang terikat apabila semakin banyak akan membuat tekstur fruit leather kenitu lebih lunak dan jaringan yang terbentuk lebih kompak sehingga gaya dibutuhkan agar dapat putus atau sobek lebih besar.

Semakin tinggi konsentrasi bahan pengikat yang ditambahkan, nilai kuat tarik fruit leather kenitu yang dihasilkan juga semakin tinggi. Artinya, gaya yang 
dibutuhkan untuk membuat fruit leather kenitu putus atau sobek semakin besar. Hal tersebut mengindikasikan bahwa fruit leather kenitu memiliki tekstur kenyal dan kompak karena adanya penambahan hidrokoloid yang dapat mengikat air dan membentuk gel. Konsentrasi hidrokoloid yang semakin tinggi menyebabkan air yang terikat dalam jaringan hidrokoloid semakin banyak (Widyaningtyas \& Susanto, 2014). Menurut Morris (1998), struktur gel yang semakin kokoh menunjukkan bahwa air yang terperangkap semakin banyak karena air yang menguap selama pengeringan semakin sedikit sehingga kadar airnya lebih tinggi. Peningkatan kadar air tersebut dapat membuat tekstur menjadi kompak (kenyal) dan plastis.

\section{Elongasi Fruit Leather Kenitu}

Elongasi merupakan selisih antara panjang saat putus (setelah ditarik oleh alat) dan panjang awal dari suatu bahan. Hasil sidik ragam $(\alpha=5 \%)$ menunjukkan bahwa variasi jenis dan konsentrasi bahan pengikat berpengaruh nyata terhadap elongasi fruit leather kenitu, sedangkan interaksi keduanya berpengaruh tidak nyata. Nilai elongasi fruit leather kenitu dengan variasi jenis dan konsentrasi bahan pengikat disajikan pada Gambar 4.

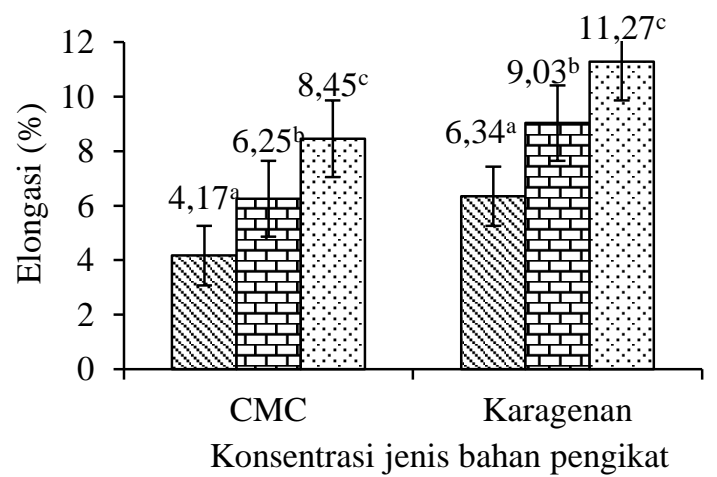

Gambar 4. Nilai elongasi fruit leather kenitu dengan variasi konsentrasi jenis bahan pengikat $0,1 \%$ (\$); $0,3 \%$ (牙); dan $0,5 \%$ ( $\because$ )

Fruit leather kenitu dengan penambahan karagenan menghasilkan elongasi yang lebih besar daripada dengan penambahan CMC. Nilai elongasi ini berbanding lurus dengan nilai kuat tarik. Nilai kuat tarik yang tinggi mengindikasikan bahwa fruit leather kenitu memiliki jaringan yang kompak dan tekstur lebih liat sehingga membutuhkan gaya lebih besar untuk putus dan nilai kuat tarik yang lebih besar dapat menyebabkan nilai elongasi juga bertambah besar. Hal tersebut dikarenakan jumlah serat pada karagenan lebih besar daripada CMC (Santoso et al., 2004; Muzaifa, 2006). Kandungan serat yang tinggi meningkatkan kemampuan menyerap air karena adanya gugus hidroksil bebas yang bersifat polar dalam jumlah yang cukup banyak (Santoso, 2011).

Semakin tinggi konsentrasi bahan pengikat yang ditambahkan, nilai elongasi fruit leather kenitu akan semakin tinggi. Nilai elongasi tersebut dipengaruhi oleh nilai kuat tarik fruit leather kenitu. Menurut Tethool (2011), semakin tinggi nilai kuat tarik (tensile strength), sifat produk semakin kompak sehingga elongasi mengalami kenaikan.

Sineresis merupakan menurunnya kemampuan jaringan protein atau polisakarida dalam mengikat air sehingga air di dalam bahan pangan akan berada di atas permukaannya (Kalab, 2000). Hasil sidik ragam $(\alpha=5 \%)$ menunjukkan bahwa variasi jenis dan konsentrasi bahan pengikat berpengaruh nyata terhadap sineresis fruit leather kenitu sedangkan interaksi keduanya berpengaruh tidak nyata. Nilai sineresis fruit leather kenitu dengan variasi jenis dan konsentrasi bahan pengikat ditunjukkan pada Gambar 5.

Fruit leather kenitu dengan penambahan karagenan memiliki nilai sineresis yang lebih kecil daripada fruit leather kenitu dengan penambahan CMC karena karagenan mengandung serat yang lebih banyak daripada CMC (Santoso et al., 2004; Muzaifa, 2006). Menurut Santoso (2011), kandungan serat yang tinggi akan meningkatkan kemampuan 
menyerap air karena di dalam serat terdapat cukup banyak gugus hidroksil bebas yang bersifat polar, sehingga kemampuan mengikat air yang lebih banyak akan membuat struktur gel semakin kuat dan sineresis pada karagenan lebih rendah dibanding menggunakan CMC.

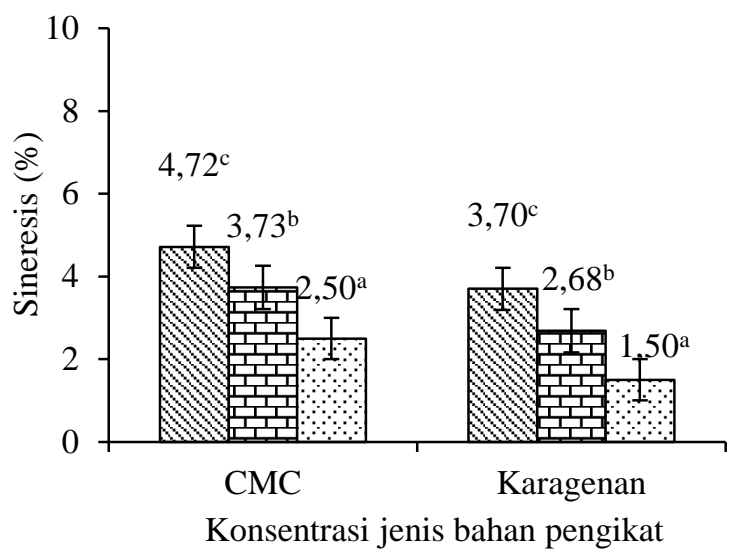

Gambar 5. Nilai sineresis fruit leather kenitu dengan variasi konsentrasi jenis bahan pengikat $0,1 \%$ (ख); $0,3 \%$ (臣); dan $0,5 \%(2)$

Semakin tinggi konsentrasi bahan pengikat yang ditambahkan, nilai sineresis fruit leather kenitu akan semakin kecil karena konsentrasi hidrokoloid yang semakin meningkat akan menyebabkan kemampuan mengikat air semakin kuat sehingga dapat menurunkan sineresis. Menurut Agustin \& Putri (2014), semakin tinggi konsentrasi hidrokoloid yang ditambahkan maka air yang terikat dalam jaringan hidrokoloid akan semakin banyak. Konsentrasi CMC dan karagenan yang semakin tinggi menyebabkan nilai sineresis semakin menurun karena semakin tinggi konsentrasi bahan pengikat maka struktur double helix yang terbentuk semakin kuat sehingga dapat menangkap dan mengikat air dalam gel.

\section{Karakteristik Kimia Fruit Leather Kenitu \\ Kadar Air Fruit Leather Kenitu}

Air pada bahan pangan merupakan komponen yang penting karena dapat mempengaruhi penampakan, tekstur, cita rasa, kesegaran, dan umur simpan (Herawati, 2008). Hasil sidik ragam $(\alpha=$ $5 \%$ menunjukkan bahwa jenis dan konsentrasi bahan pengikat berpengaruh nyata terhadap kadar air fruit leather kenitu sedangkan interaksi keduanya berpengaruh tidak nyata. Nilai kadar air fruit leather kenitu dengan variasi jenis dan konsentrasi bahan pengikat ditunjukkan pada Gambar 6.

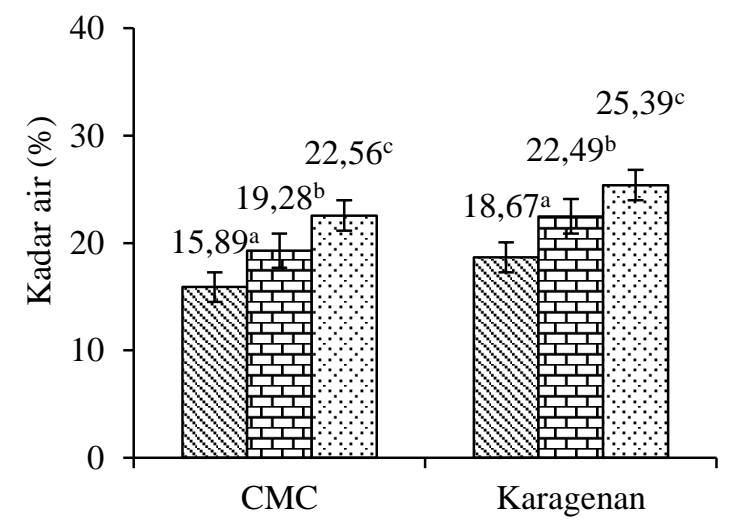

Konsentrasi jenis bahan pengikat

Gambar 6. Nilai kadar air fruit leather kenitu dengan variasi konsentrasi jenis bahan pengikat $0,1 \%$ ( $) ; 0,3 \%$ (모); dan $0,5 \%$ ( $\because \therefore$ )

Fruit leather kenitu dengan penambahan karagenan memiliki kadar air yang lebih tinggi daripada fruit leather kenitu dengan penambahan CMC karena perbedaan jumlah serat pada bahan pengikat yang digunakan sehingga dapat mempengaruhi kemampuan mengikat air fruit leather kenitu yang dihasilkan. Semakin tinggi konsentrasi bahan pengikat yang ditambahkan, kadar air dalam fruit leather kenitu akan semakin tinggi. Hidrokoloid memiliki kemampuan untuk menurunkan kandungan air bebas dalam bahan pangan (Garbutt, 1997). Konsentrasi bahan pengikat yang semakin tinggi menyebabkan kadar air fruit leather kenitu semakin tinggi. Menurut Syarief \& Hariyadi (1993), tinggi rendahnya kadar air suatu bahan sangat ditentukan oleh air terikat dan air bebas yang terdapat dalam 
bahan. Air terikat ini membutuhkan suhu yang lebih tinggi untuk menguapkannya apabila dibandingkan dengan air bebas yang membutuhkan suhu yang relatif rendah untuk menguapkannya. Menurut SNI 01-1718-1996, manisan buah kering memiliki batas maksimal kadar air sebesar $25 \%$. Semua perlakuan sudah memenuhi batas maksimal kadar air manisan buah kering kecuali perlakuan 0,5\% karagenan.

\section{Kadar Serat Kasar Fruit Leather Kenitu}

Serat kasar (crude fiber) adalah bagian dari karbohidrat yang tidak dapat dihidrolisis oleh asam atau basa kuat pada kondisi terkontrol (Suparjo, 2010). Hasil sidik ragam $(\alpha=5 \%)$ menunjukkan bahwa variasi jenis dan konsentrasi bahan pengikat berpengaruh nyata terhadap kadar serat kasar fruit leather kenitu, sedangkan interaksi keduanya berpengaruh tidak nyata. Nilai kadar serat kasar fruit leather kenitu dengan variasi jenis dan konsentrasi bahan pengikat ditunjukkan pada Gambar 7.

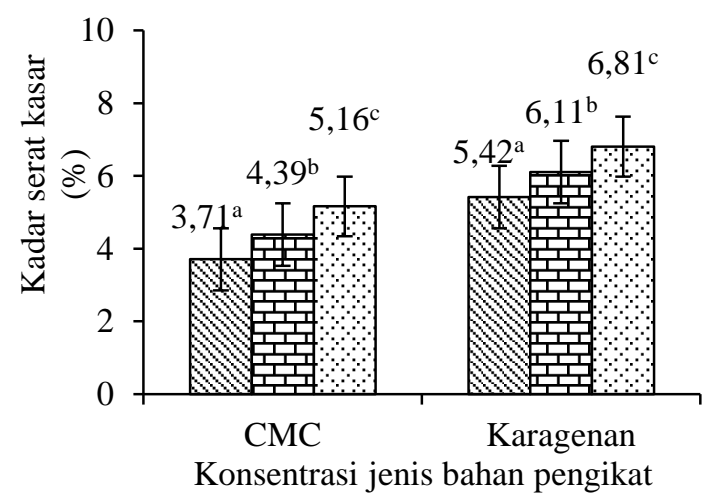

Gambar 7. Nilai kadar serat kasar fruit leather kenitu dengan variasi konsentrasi jenis bahan pengikat $0,1 \%(\mathbb{N}) ; 0,3 \%$ (当); dan $0,5 \%$ ( $\because$ )

Fruit leather kenitu dengan penambahan karagenan menghasilkan kadar serat kasar yang lebih tinggi daripada fruit leather kenitu dengan penambahan CMC. Kadar serat kasar yang semakin tinggi dikarenakan kandungan serat karagenan lebih tinggi daripada CMC.
Penggunaan kappa karagenan pada penelitian ini menyebabkan kandungan serat pada fruit leather kenitu lebih tinggi dibanding CMC karena karagenan jenis ini mampu meningkatkan kadar serat, semakin tinggi penggunaan karagenan maka semakin tinggi pula kadar serat fruit leather (Tondang et al., 2018).

Semakin tinggi konsentrasi bahan pengikat yang ditambahkan, kadar serat kasar dalam fruit leather kenitu semakin tinggi karena karagenan mengandung total serat pangan sebesar 83,62 g/ $100 \mathrm{~g}$ (Santoso et al., 2004), sedangkan kandungan serat pada CMC sebesar $74 \mathrm{~g} /$ $100 \mathrm{~g}$ sehingga semakin tinggi konsentrasinya maka kandungan serat juga akan semakin tinggi (Muzaifa, 2006). Kadar serat kasar berbanding lurus dengan kadar air dimana semakin tinggi kadar serat kasar fruit leather kenitu maka air yang terserap akan semakin banyak sehingga kadar air fruit leather kenitu akan semakin tinggi.

\section{Karakteristik Organoleptik Fruit Leather Kenitu \\ Tingkat Kesukaan Warna Fruit Leather Kenitu}

Menurut Rosida et al. (2016), salah satu karakteristik fruit leather yang diharapkan yaitu memiliki warna yang menarik. Hasil uji Chi-square $(\alpha=5 \%)$ menunjukkan bahwa nilai signifikansi warna fruit leather kenitu lebih besar daripada nilai signifikansi tabel (44,32 > $43,77)$ sehingga perlakuan variasi jenis dan konsentrasi bahan pengikat berpengaruh nyata terhadap tingkat kesukaan warna panelis. Persentase tingkat kesukaan panelis terhadap warna fruit leather kenitu dengan variasi konsentrasi CMC dan karagenan sebagai bahan pengikat ditunjukkan pada Tabel 2.

Persentase tingkat kesukaan panelis terhadap warna fruit leather kenitu tertinggi yaitu $86,33 \%$ pada perlakuan A1B2 (0,3\% CMC). Kristina (2016) menyebutkan bahwa CMC yang 
ditambahkan dapat mengikat air dalam produk sehingga dapat mempengaruhi kepekatan warna dan akan membuat warna fruit leather yang dihasilkan semakin pekat. Panelis lebih menyukai warna fruit leather kenitu dengan penambahan $0,3 \%$ CMC dikarenakan warna yang dihasilkan tidak terlalu cerah atau tidak terlalu gelap. Kemampuan karagenan dalam mengikat air lebih besar daripada CMC sehingga perlakuan dengan penambahan karagenan menghasilkan warna yang lebih gelap dan kurang disukai panelis. Kecerahan warna pada fruit leather kenitu dapat dipengaruhi oleh adanya reaksi pencoklatan enzimatis, reaksi maillard dan juga dimungkinkan karena adanya reaksi karamelisasi.

Tabel 2. Persentase tingkat kesukaan panelis terhadap warna fruit leather kenitu dengan variasi konsentrasi CMC dan karagenan sebagai bahan pengikat

\begin{tabular}{ccccc}
\hline Perlakuan & $\begin{array}{c}\text { Agak } \\
\text { suka } \\
(\%)\end{array}$ & $\begin{array}{c}\text { Suka } \\
(\%)\end{array}$ & $\begin{array}{c}\text { Sangat } \\
\text { suka } \\
(\%)\end{array}$ & $\begin{array}{c}\text { Jumlah } \\
\text { kesukaan } \\
(\%)\end{array}$ \\
\hline A1B1 & 36,67 & 23,33 & 0 & 60 \\
AIB2 & 20 & 53,33 & 13,33 & 86,66 \\
AIB3 & 33,33 & 13,33 & 0 & 46,66 \\
A2B1 & 36,67 & 10 & 3,33 & 50 \\
A2B2 & 40 & 30 & 3,33 & 73,33 \\
A2B3 & 33,33 & 23,33 & 6,67 & 63,33 \\
\hline
\end{tabular}

Keterangan: A1 (CMC), A2 (karagenan), B1 $(0,1 \%), \mathrm{B} 2(0,3 \%)$, dan B3 $(0,5 \%)$

\section{Tingkat Kesukaan Aroma Fruit Leather Kenitu}

Aroma fruit leather umumnya sesuai dengan aroma bahan baku yang digunakan tetapi terkadang juga diberi aroma sintetis. Pada penelitian ini tidak dilakukan pemberian flavor lain selain dari buah kenitu yang digunakan. Hasil uji Chisquare $(\alpha=5 \%)$ menunjukkan perlakuan variasi jenis dan konsentrasi bahan pengikat berpengaruh tidak nyata terhadap tingkat kesukaan aroma panelis. Hal tersebut dikarenakan aroma alami buah kenitu lemah. Aroma karamel juga muncul pada fruit leather kenitu diduga karena terjadinya reaksi karamelisasi. Aroma yang timbul hampir sama sehingga panelis tidak dapat membedakan aroma dari masingmasing perlakuan.

\section{Tingkat Kesukaan Tekstur Fruit Leather Kenitu}

Menurut Rosida et al. (2016) salah satu karakteristik fruit leather yang diharapkan yaitu memiliki tekstur yang sedikit liat dan kompak. Hasil uji Chisquare $(\alpha=5 \%)$ menunjukkan perlakuan variasi jenis dan konsentrasi bahan pengikat berpengaruh nyata terhadap tingkat kesukaan tekstur panelis. Hal tersebut dikarenakan fruit leather kenitu yang dihasilkan memiliki tekstur yang cukup liat dan kompak. Persentase tingkat kesukaan panelis terhadap tekstur fruit leather kenitu dengan variasi konsentrasi CMC dan karagenan sebagai bahan pengikat ditunjukkan pada Tabel 3.

Tabel 3. Persentase tingkat kesukaan panelis terhadap tekstur fruit leather kenitu dengan variasi konsentrasi CMC dan karagenan sebagai bahan pengikat

\begin{tabular}{ccccc}
\hline Perlakuan & $\begin{array}{c}\text { Agak } \\
\text { suka } \\
(\%)\end{array}$ & $\begin{array}{c}\text { Suka } \\
(\%)\end{array}$ & $\begin{array}{c}\text { Sangat } \\
\text { suka } \\
(\%)\end{array}$ & $\begin{array}{c}\text { Jumlah } \\
\text { kesukaan } \\
(\%)\end{array}$ \\
\hline A1B1 & 20 & 10 & 0 & 30 \\
AIB2 & 30 & 13,34 & 3,33 & 46,67 \\
AIB3 & 23,33 & 6,67 & 6,67 & 36,67 \\
A2B1 & 36,67 & 16,67 & 3,33 & 56,67 \\
A2B2 & 20 & 46,66 & 6,67 & 73,33 \\
A2B3 & 20 & 30 & 6,67 & 56,67 \\
\hline
\end{tabular}

Keterangan: A1 (CMC), A2 (karagenan), B1 $(0,1 \%), \mathrm{B} 2(0,3 \%)$, dan B3 $(0,5 \%)$

Persentase tingkat kesukaan panelis terhadap tekstur fruit leather kenitu tertinggi yaitu $73,34 \%$ pada perlakuan A2B2 yakni tidak terlalu liat dan juga tidak terlalu lunak. Hal tersebut dipengaruhi oleh adanya kadar air dimana semakin tinggi penambahan konsentrasi hidrokoloid maka tekstur semakin lunak (kompak) karena air yang terikat semakin banyak (Pietrasik \& Jarmolouk, 2003). 


\section{Tingkat Kesukaan Rasa Fruit Leather Kenitu}

Rasa merupakan faktor penting dalam menentukan penerimaan atau penolakan terhadap makanan oleh panelis (Estiasih \& Ahmadi, 2009). Hasil uji Chisquare $(\alpha=5 \%)$ menunjukkan perlakuan variasi jenis dan konsentrasi bahan pengikat berpengaruh tidak nyata terhadap tingkat kesukaan rasa panelis. Hal tersebut dikarenakan jenis bahan pengikat yang ditambahkan tidak memiliki rasa (hambar).

Fruit leather kenitu yang dihasilkan memiliki rasa manis dengan sedikit rasa asam yang disebabkan oleh adanya penambahan gula kristal putih, asam sitrat, dan rasa manis dari daging buah kenitu sehingga semua perlakuan memiliki rasa yang cenderung sama.

\section{Tingkat Kesukaan Keseluruhan Fruit Leather Kenitu}

Penilaian keseluruhan merupakan penilaian akhir yang diamati oleh panelis. Hasil uji Chi-square $(\alpha=5 \%)$ menunjukkan perlakuan variasi konsentrasi CMC dan karagenan sebagai bahan pengikat berpengaruh tidak nyata terhadap tingkat kesukaan keseluruhan panelis.

\section{Perlakuan Terbaik Fruit Leather Kenitu}

Penentuan perlakuan terbaik

dilakukan secara deskriptif kualitatif dengan pembobotan nilai terhadap parameter-parameter yang berkontribusi terhadap karakteristik fruit leather kenitu. Parameter-parameter yang digunakan dalam penentuan perlakuan terbaik fruit leather kenitu yaitu sineresis, kadar air, dan organoleptik (warna dan tekstur). Setiap parameter yang berkontribusi terhadap karakteristik fruit leather kenitu ditunjukkan pada Tabel 4.

Parameter yang sesuai dengan SNI 01-1718-1996 diberi nilai tertinggi (4) sedangkan yang tidak sesuai diberi nilai terendah (0). Sineresis fruit leather kenitu yang dikehendaki memiliki nilai terendah dari seluruh perlakuan. Kadar air fruit leather kenitu yang dikehendaki memiliki nilai yang sesuai dengan SNI manisan buah kering (maksimal 25\%). Hasil yang dikehendaki dari organoleptik warna dan tekstur yaitu perlakuan dengan nilai persentase kesukaan tertinggi.

Tabel 4. Kontribusi setiap parameter terhadap karakteristik fruit leather kenitu

\begin{tabular}{|c|c|c|c|c|c|c|}
\hline \multirow[b]{2}{*}{ Parameter } & \multicolumn{6}{|c|}{ Perlakuan } \\
\hline & $\frac{\bar{n}}{2}$ & $\frac{\tilde{\vartheta}}{\gtrless}$ & $\stackrel{\oplus}{\gtrless}$ & $\bar{c}$ & 華 & $\frac{\tilde{y}}{2}$ \\
\hline Sineresis & 1 & 2 & 3 & 2 & 3 & 4 \\
\hline Kadar Air & 4 & 2 & 1 & 2 & 1 & 0 \\
\hline $\begin{array}{l}\text { Organoleptik } \\
\text { Warna }\end{array}$ & 2 & 4 & 1 & 1 & 3 & 2 \\
\hline $\begin{array}{l}\text { Organoleptik } \\
\text { Tekstur }\end{array}$ & 1 & 2 & 1 & 3 & 4 & 3 \\
\hline Total & 8 & 10 & 6 & 8 & 11 & 9 \\
\hline
\end{tabular}

Keterangan: A1 (CMC), A2 (karagenan), B1 $(0,1 \%), \mathrm{B} 2(0,3 \%)$, dan B3 $(0,5 \%)$

Perlakuan terbaik yang terpilih yaitu A2B2 (0,3\% karagenan) dengan jumlah nilai 11. Fruit leather kenitu dengan penambahan $0,3 \%$ karagenan (A2B2) memiliki nilai kecerahan warna (lightness) sebesar 54,48; tekstur $348 \mathrm{~g} / 2 \mathrm{~mm}$; kuat tarik 17,99 KPa; elongasi 9,03\%; sineresis 2,68\%; kadar air 22,49\%; kadar serat kasar $6,11 \%$; kesukaan warna $73,33 \%$; kesukaan aroma $63,33 \%$; kesukaan tekstur 73,33\%; kesukaan rasa $60 \%$; dan kesukaan keseluruhan $66,67 \%$.

\section{KESIMPULAN}

Variasi konsentrasi CMC dan karagenan sebagai bahan pengikat tidak berpengaruh nyata $(\alpha=5 \%)$ terhadap karakteristik fisik, kimia dan pada kesukaan panelis parameter aroma, rasa, namun berpengaruh nyata terhadap tingkat kesukaan panelis (warna dan tekstur). Perlakuan terbaik yang terpilih adalah pengunaan konsentarsi 0,3\% karagenan. 


\section{DAFTAR PUSTAKA}

Agustin, F., dan Putri, R.W.D. 2014. Pembuatan jelly drink Averrhoa blimbi L. (Kajian proporsi belimbing wuluh: air dan konsentrasi karagenan). Jurnal Pangan dan Agroindustri, 2 (3) : 1-9.

American Standard Testing and Material (ASTM). 1995. D 3039: Standart Test Methods for Tensile Properties of Plastic.American Society of Testing and Materials, USA.

Association of Official Analytical Chemistry (AOAC). 2005. Official Method of Analysis The Association of Official Analytical Chemistry. Association of Official Chemist, Washington D.C.

Badan Standarisasi Nasional. 1996. SNI 011718-1996: Manisan Buah Kering. BSN Indonesia, Jakarta.

Estiasih, T., dan Ahmadi, K. 2009. Teknologi Pengolahan Pangan. Bumi Aksara, Jakarta.

Garbutt, J. 1997. Essentials of Food Microbiology. Arnold, London.

Herawati, H. 2008. Penentuan umur simpan pada produk pangan. Jurnal Litbang Pertanian, 27 (4): 124-130.

Herbstreith, K., dan Fox, G. 2009. Jams, jellies, dan marmalades. (www.herbstreithfox.de/ fileadmin/tmpl/broschueren/konfituere_e nglish.pdf). [Diakses tanggal 20 Juni 2018].

Kalab, M. 2000. Yoghurt: electron microscopy. (http://www.aka.livstek.lth.se). [Diakses tanggal 4 Juni 2018].

Kristina, S. A. 2016. "Pengaruh Variasi Konsentrasi CMC-Na terhadap Mutu Fisik dan Penerimaan Volunteer Selai Apel Lembaran". Skripsi. Akademi Analisis Farmasi dan Makanan, Putra Indonesia Malang, Malang.

Kusbiantoro, B., Herawati, H., dan Ahza, A.B. 2005. Pengaruh jenis dan konsentrasi bahan penstabil terhadap mutu produk velva labu jepang. Jurnal Hortikultura, 15 (3): 223-230.
Kwartiningsih, E., dan Mulyati, L.N.S. 2005. Fermentasi sari buah nanas menjadi vinegar. Ekuilibrium, 4 (1): 8-12.

Luo, X.D., Basile, M.J., and Kennelly, E.J. 2002. Polyphenol antioxidants from the fruits of Chrysophyllum cainito L. (star apple). Journal of Agricultural and Food Chemistry, 50 (6): 1379-1382.

Marzelly, A.D., Yuwanti, S., dan Lindriati, T. 2017. Karakteristik fisik, kimia, dan sensoris fruit leather pisang ambon (Musa paradisiaca S.) dengan penambahan gula dan karagenan. Jurnal Agroteknologi, 11 (2): 172-185.

Morris, V.J. 1998. Gelation of Polysaccharides. Aspen Publ, Gaithersburg.

Muzaifa, M. 2006. Pembuatan CMC (carboxymethyl cellulose) dari selulosa bakterial (nata de coco). Agrista. 10 (2): 100-106.

Nuh, M. 2018. Pengaruh penambahan kelopak bunga rosella pada pembuatan fruit leather dari buah mangga. AGRINTECH: Jurnal Teknologi Pangan dan Hasil Pertanian, 1 (2): b117-122.

Pietrasik, Z., and Jarmolouk, A. 2003. Effect sodium cassinate and $\mathrm{k}$-carragenan on binding and textural properties of muscle gels enhanced by microbial transglutaminase addition. Journal of Food Engineering, 6 (3): 285-294.

Pomeranz, Y., and Meloans, C.E. 1994. Food Analysis Theory and Practice. Nostrand Reinhold Company, New York.

Raab, C., and Oehler, N. 2000. Making Dried Fruit Leather. Oregon State University, US

Rahman, P., Pato, U.,dan Harun,N. 2016. Pemanfaatan buah pedada (Sonnetaria caseolaris) dan buah naga merah (Hylocereus polyrhizus) dalam pembuatan fruit leather. Jurnal Program Studi Teknologi Hasil Pertanian. Jurusan Teknologi Hasil Pertanian. Fakultas Pertanian. Universitas Riau Pekanbaru, 3 (2): 1-15. 
Rosida, K.B, Enny, dan Reny, Z.H. 2016. Pengembangan produk fruit leather dari buah sirsak dan bunga rosella. $J$. Rekapangan, 10 (1): 61-66

Ruiz, A.C., and Pavon. 1999. Star apple: Chrysophyllum cainito L. (https://hort. purdue.edu/newcrop/morton/star_apple.h tml). [Diakses tanggal 25 Juni 2018].

Santoso, A. 2011. Serat pangan (dietary fiber) dan manfaatnya bagi kesehatan. Magistra No. 75 Th. XXIII Maret 2011. ISSN 0215-9511: 35-40.

Santoso, J., Yumiko, Y., dan Takeshi, S. 2004. Mineral, fatty acid, and dietary fiber compositions in several Indonesian seaweeds. Jurnal Ilmu Perairan dan Perikanan Indonesia, 2 (1): 45-51.

Setyaningsih, D., Apriyantono, A., dan Sari, M.P. 2010. Analisis Sensori untuk Industri Pangan dan Agro. IPB Press, Bogor.

Sidi, C., Widowati, E., Nuraiwi, A. 2014. Pengaruh penambahan karagenan pada karakteristik fisikokimia dan sensoris fruit leather nanas (Ananas comosus $\mathrm{L}$. Merr.) dan wortel (Daucus carota). Jurnal Aplikasi Teknologi Pangan, 4: 122-127.

Sudarmadji, S., Bambang, H., dan Suhardi. 1997. Prosedur Analisa untuk Bahan Makanan dan Pertanian. Liberty, Yogyakarta.

Sugiyono. 2004. Kimia Pangan. Universitas Negeri Yogyakarta, Yogyakarta.

Sugiyono. 2016. Metode Penelitian Kuantitatif, Kualitatif, dan $R \& D$. PT Alfabet, Bandung.

Suparjo. 2010. Analisis Bahan Pakan Secara Kimiawi: Analisis Proksimat dan Analisis Serat. Laboratorium Makanan Ternak, Fakultas Peternakan, Universitas Jambi, Jambi.

Syarief, R., dan Hariyadi, H. 1993. Teknologi Penyimpanan Pangan. PAU IPB, Bogor.
Taruna, I., dan Sutarsih. 2011. "Identifikasi Sifat Fisik dan Sifat Mekanik Buah Kenitu (Chrysophyllum cainito) Berdasarkan Varietas dan Lokasi Pertumbuhannya di Wilayah Jawa Timur". Laporan Penelitian Fundamental. Fakultas Teknologi Pertanian, Universitas Jember, Jember.

Tethool, E.F. 2011. "Pengaruh Heat Moisture Treatment, Penambahan Gliserol Monostearat, serta Rasio Campuran Tepung Singkong dan Pati Sagu terhadap Sifat Fisikokimia Sohun". Tesis. Fakultas Ilmu dan Teknologi Pangan, Universitas Gajah Mada, Yogyakarta.

Tondang, H.M., Gusti, A.E.I, dan Wiadnyani, S. 2018. Pengaruh penambahan karagenan terhadap karakteristik fruit leather terhadap buah naga merah (Hylocereus polyrizus). Jurnal ITEP, 7 (2): 33-42.

Widyaningtyas, M., dan Susanto, W.H. 2014. Pengaruh jenis dan konsentrasi hidrokoloid (Carboxy Methyl Cellulose, xanthan gum, dan karagenan) terhadap karakteristik mie kering berbasis pasta ubi jalar varietas kuning. Jurnal Pangan dan Agroindustri, 3 (2): 417-423.

Winarno 1992. Kimia Pangan dan Gizi. PT. Gramedia Pustaka Utama, Jakarta.

Yahia, E.M., and Orozco, F.G. 2011. Postharvest Biology and Technology of Tropical and Subtropical Fruits: Star Apple (Chrysophyllum cainito L.). Woodhead Publishing Limited, Mexico. 